\title{
110. 画像診断に求ける肉眼の識別能
}

Discriminating Power of Human's Eyes on Radiological Imaging

北海道医療大学雪学部附属病院放射線部 Division of Radiology Health Science University of Hokkaido Hospital
○翰嶋隆博 竹腰光男 藤田智

OTakahiro WAJIMA, Mitsuo TAKEKOSHI and Satoshi FUJITA

（目的）近年、画像診断機器の進歩は著しく、またその普及度も急速である。しかしながらディジタ ル画像診断㙨器が普遍的なものになりつつある現状においても、画像診断はあくまで観察者の肉眼によつ て最終的に評価される。継続して病変の状況を画像上で観察する場合においても、病変の大きさの変化は ます肉眼で比較した印象で判断するというのが一般的であろう。画像診断をおこなう際に、画像を認識 するさまざまな要素のなかで大きさの認識（長さ・面積・大小の比較判定など）はきわめて重要である。 いつぽう、肉眼による画像判読能力は観察者の画像認識能力によって左右され、観察者の主観に負うとこ ろが大きい。われわれは肉眼による大きさの識別能力がどの程度のものか基礎的な調查をおこない、識別 の「しきい值」を知ると共にこれが再現画像評価法のパラメータになり得るか娭討することとした。

（方法）実験方法はX線フィルム上に不透過像の基準像を作成し、これの捘大・樎小像と基準像を並 ベて被験者に比較させて回答させる方法でおこなった。拡大・縮小率は０\%・2．5\%・5\%・10\%と し 各サイス 5 枚づつ計 35 枚について基準像と比べて 大きい・小さい・同じとする官能試験法によ つておこない、正誤率をみることとした。この実験により大きさの識別能の：きい值を求めることとした。 被験者は歯科医師・放射線技師・登院実習生 計 30 名とした。また各グル・ソによって識別の感度に有 意差があるかROC解析も併せておこなつた。

(系志军）われわれの実験の結果、肉眼による大きさの識別能は5\%の大きさの変化から低下してい ることが判明した。このことから識別能のしきい值は $5 \%$ ～ $10 \%$ 長さの変化にあるのではないかと推 察された。このしきい值は画像評価のパラメータとして同一部位を繰り返し撮影する再現画像の評価の際 に有用であると考えられた。すなわち、同一部位を撮影した場合 当該部分の大きさの変化が $10 \%$ 未満 である場合は画像の差異はさほど目立たず、再現度は概ね良好な印象を与えると思われるが $10 \%$ \%超え た場合は一瞥して差異が認められることが考えられた。以上のことから通常の診断目的の画像診断の場合 再現性を考慮する場合には画像の変化の許容度は少なくとも10\%の変化に抑える必要があると考えた。

Fig. 1

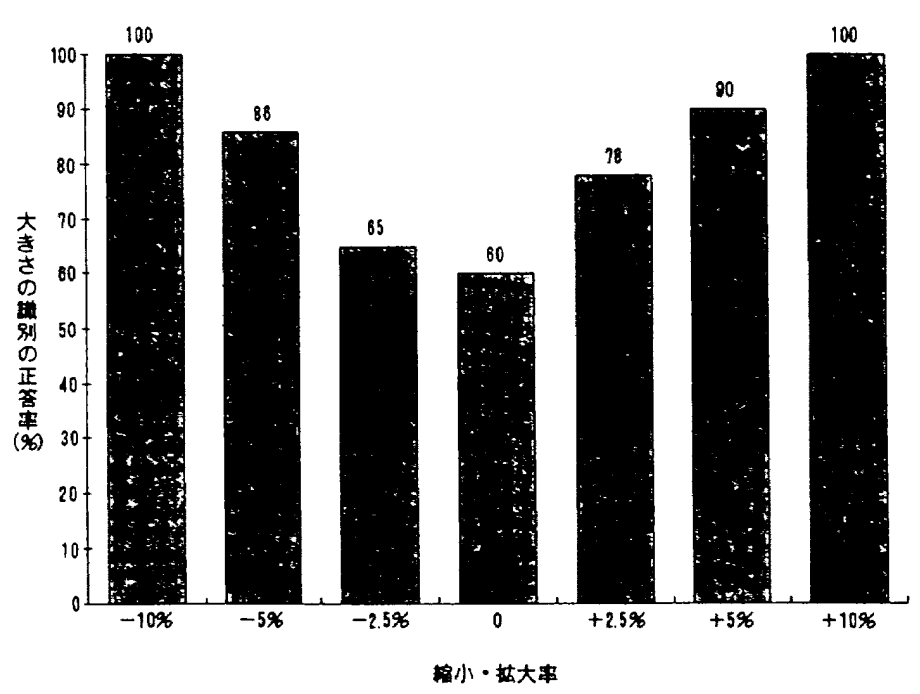

Fig.2 各グループ毎の識別の感度を示すROC曲線

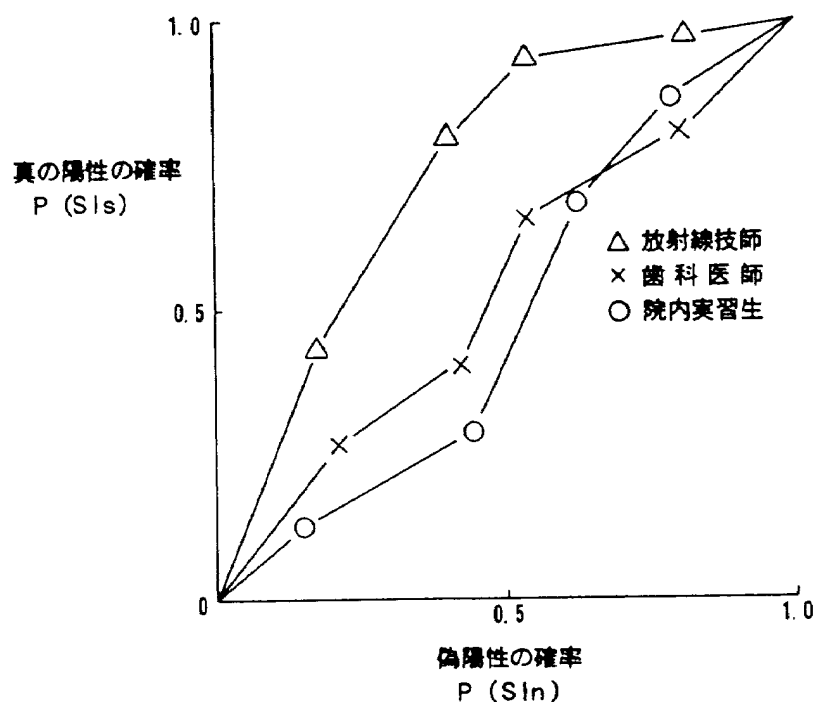

